\title{
AUDITORS’ PERCEPTION OF FRAUD PREVENTION MEASURES: EVIDENCE FROM TURKEY
}

\author{
Evren Dilek Sengur ${ }^{1}$
}

\begin{abstract}
The study has been carried out to identify auditors' perception regarding fraud prevention measures. In particular, the research focuses on the differences in perception of the effectiveness of fraud prevention measures among three categories of fraud: fraudulent financial statement, misappropriation of assets and corruption. In the analysis Friedman test and Wilcoxon test were used to examine differences in perception of the effectiveness of fraud prevention measures. The results of the analysis show that there are significant differences in terms of auditors' ranking of fraudulent financial statements, misappropriation of assets and corruption for the following fraud prevention measures: establishing corporate code of conducts, effective audit commitee, and external auditors. Additionally, respondents have significant difference in their opinion regarding the effectiveness of developing an appropriate oversight process in preventing fraudulent financial statement, misappropriation of assets and corruption.
\end{abstract}

Keywords: Fraud prevention, fraud prevention measures, prevention of fraudulent financial statements, prevention of misappropriation of assets, prevention of corruption.

JEL Code: M42

\section{Introduction}

The word fraud is a generic term used to describe any deliberate act to deceive or mislead another person, causing harm or injury. This intentional act can be differentiated and defined in many ways (Rezaee, 2002). Occupational fraud is defined as the use of one's occupation for personal enrichment through the deliberate misuse or misapplication of the employing organization's resources or assets (ACFE, 2010). Association of Certified Fraud Examiners (ACFE) classifies corporate fraud into three categories: fraudulent financial statements, misappropriation of assets and corruption. Fraudulent financial statment involves intentional misstatements including omissions of amounts or disclosures in financial statements to deceive financial statement users. Misappropriation of assets involves the theft of an entity's assets and can be accomplished in various ways, including embezzling receipts, stealing assets, or causing an entity to pay for goods or services that have not been received. Misappropriation of assets may be accompanied by false or misleading records or documents, possibly created by circumventing controls (SAS 99 .06). Corruption schemes involve the employee's use of his or her influence in business transactions in a way that violates his or her duty to the employer for the purpose of obtaining a benefit for him or herself or someone else (ACFE, 2010).

Fraud prevention is all the measures that can be used to stop fraud from occuring. According to 2010 Report to the Nations on Occupational Fraud and Abuse, a typical organization annually loses $5 \%$ of its revenues to fraud. Fraud prevention impedes fraud incidence and reduces loss of companies. In 2002, American Institute of Certified Public Accountants (AICPA) has issued an Exhibit to SAS 99 entitled "Management Anti-Fraud Programs and Controls, Guidance to Help Prevent, Deter, and Detect Fraud" (SAS 99 .86). It was issued jointly by the American Institute of Certified Public Accountants (AICPA), Association of Certified Fraud Examiners (ACFE), Financial Executives International, Information Systems Audit and Control Association, The

\footnotetext{
1 Istanbul University, Faculty of Business and Administration, Department of Accounting, Istanbul, Turkey, e-mail: sengur@istanbul.edu.tr
} 
Institute of Internal Auditors (IIA), Institute of Management Accountants, Society for Human Resource Management. The exhibit points out that entities can take three actions to mitigate fraud: create a culture of honesty and high ethics, evaluate antifraud processes and controls, and develope an appropriate oversight process. Those programs and controls ensure entitiy to reduce or eliminate the risk of fraudulent financial statement, misappropriation of assets and corruption.

This study has been undertaken to identify the external and internal auditors' opinion regarding the fraud prevention measures. In particular, the research focuses on understanding the auditors' opinion regarding the effectiveness of fraud prevention measures for each of the three categories of fraud: fraudulent financial statement, misappropriation of assets and corruption. Furthermore, the study examines the differences in perception of effectiveness of fraud prevention measures among fraudulent financial statement, misappropriation of assets and corruption.

\section{Fraud Prevention Measures}

In this study, fraud prevention measures are subcategorized in compliance with SAS 99 Exhibit "Management Anti-Fraud Programs and Controls, Guidance to Help Prevent, Deter, and Detect Fraud". In total 14 fraud prevention measures have identified for 3 main fraud prevention measures. Those measures are described as followed:

Creating a culture of honesty and high ethics

- Setting the tone at the top: Tone at the top refers to the ethical atmosphere that is created in the workplace by the organization's leadership. If the tone set by managers upholds ethics and integrity, employees will be more inclined to uphold those same values. However, if upper management appears unconcerned with ethics and focuses solely on the bottom line, employees will be more prone to commit fraud because they feel that ethical conduct is not a focus or priority within the organization (ACFE).

-Establishing corporate code of conduct: A code of conduct is a policy or procedure that is specifically targeted to reduce unethical behavior (Schnatterly, 2003). Companies should create and distribute a code of conduct to all employees. However, merely having a code of conduct is not sufficient. It must be communicated frequently (Albrecht et al., 2009).

-Taking consistent actions in response to an alleged fraud: A person may be more likely to behave unethically if the perceived consequences will not be punished (Carpenter, 2005). Thus, fraudulent behavior should not be tolerated, on the contrary, it should always be denigrated and condemned (Krummeck, 2000).

-Fraud training for employees and management: Employees should participate in fraud awareness program that educates them about what is acceptable and unacceptable, how all parties, including them, are hurt when someone is dishonest, and what actions they should take if they see someone doing something improper (Albrecht et. al., 2009). Fraud awareness training enhances the consciousness of employees and helps to prevent fraud.

-Conducting background investigations on individuals being considered for employment: Companies should have effective policies that minimize the chance of hiring or promoting individuals with low levels of honesty, especially for positions of trust (Biegelman, 2006).

-Creating a positive workplace environment: A positive working environment can promote ethical behavior among employees. When employees feel secure in their jobs and valued as people, they are less likely to justify stealing from the company (Coenen, 2008). Autocratic rather than participative management, perceived inequities in the organization, unreasonable budget expectation, and low organizational loyalty can be given as factors that detract from a positive work environment (Biegelman, 2006). 
Evaluating antifraud processes and controls

-Identifying and measuring fraud risks: Management has primary responsibility for establishing and monitoring all aspects of the entity's fraud risk assessment and prevention activities. The fraud risk assessment process should consider the vulnerability of the entity to fraudulent activity and whether any of those exposures could result in a material misstatement of the financial statements or material loss to the organization (SAS 99.86 ).

-Implementing and monitoring appropriate preventive and detective internal controls: Once fraud risk assessment has taken place, the entity can identify the processes, controls, and other procedures that are needed to mitigate the identified risks (SAS 99.86 ). Thus, it is crucial to obtain understanding the kinds of preventive factors that are needed within the environment in which fraud occured (Albrecht et. al., 2009).

-Making changes to the entity's activities and processes in order to reduce or eliminate fraud risk: It is possible to reduce or eliminate certain fraud risk by making changes to the entity's activities and processes (Biegelman, 2006). Having a good system of controls means that there will be an explicit study of all frauds and why they occured, together with implementation of control activities necessary to prevent future occurences of the same types of frauds (Albrecht et. al., 2009).

Developing an appropriate oversight process

-Effective audit committee: The audit committee plays an important role in helping the board of directors fulfill its oversight responsibilities with respect to the entity's financial reporting process and the system of internal control. In exercising this oversight responsibility, the audit committee should evaluate management's identification of fraud risks and implementation of antifraud measures (SAS 99 .86).

-Management effectiveness in overseeing activities: Management has the responsibility to maintain controls that provide reasonable assurance that adequate control exists over the entity's assets and controls (Messier F.W. et. al., 2008). The fair presentation of financial statements is the responsibility of management, and, accordingly, management is responsible for prevention and detection of fraud (Rezaee, 2002).

-External audit: Independent auditors can assist management and the board of directors (or audit committee) by providing an assessment of the entity's process for identifying, assessing, and responding to the risks of fraud (SAS 99.86 ).

-Internal audit: The internal audit's objectives are to improve the effectiveness of risk management, control and governance. Internal audit function raises fraud awareness within an organization, including encouraging the audit committee and senior management to set the proper tone at the top, create control consciousness and help develop credible response to the potential risk of fraud (Reding et. al., 2007).

-Certified fraud examiners in internal audit team or in external audit team: Certified fraud examiners may assist the audit committee and board of directors with aspects of the oversight process either directly or as part of a team of internal auditors or independent auditors (SAS 99 .86).

\section{Literature Review}

In Turkey there are some studies focused on auditors' opinion regarding fraud prevention and detection. Ata et al.(2009), examined the perception of auditors regarding fraud risk indicators. The result of the study indicated that management's effectiveness in control environment is perceived as the most significant fraud risk indicator by external auditors from Gaziantep, Turkey and London, England. Additionally, in the study operational and financial stability is defined as the second most important indicator and industry circumstances is defined as the third one. Özbirecekli and Süslü (2005) carried out a survey in order to explore how auditing firms in Turkey assess fraud risks. They found that experienced external auditors (more than 40 years old) perform obtaining an 
understanding of corporate governance system of companies as the most common procedure to identify fraud risk factors.

Results from analysis of fraud and no-fraud firms Beasley (1996), concluded that no-fraud firms have boards with significantly higher percentages of outside members than fraud firms. Additionally, he pointed out that as outside director ownership in the firm and outside director tenure on the board increase, and as the number of outside directorships in other firms held by outside directors decreases, the likelihood of financial statement fraud decreases. Uzun et al. (2004) examined how various characteristics of the board of directors and other governance features affect the occurrence of corporate fraud. They found that, as the number of independent outside directors increase on a board and in the board's audit and compensation committees, the likelihood of corporate wrongdoing decreases. Coram et al. (2004) found that organizations with an internal audit function are more likely to detect fraud. According to study about internal audit structure, James (2003) did not find a difference in users perceptions of financial statement fraud prevention between outsourced internal audit teams and inhouse internal audit departments when both report to the audit committee. The study carried out by Beasley et al. (2000) provides evidence that the fraud companies have less independent audit committees, less independent boards, fewer audit committee meetings and less internal audit support. Similarly, Alleyne and Howard (2005) found that companies who have internal auditors, sound internal controls and effective audit committees are better equipped to deal with fraud prevention and detection. Schnatterly (2003) conducted a research on corporate governance structure and white-collar crime. The findings show clear policies and procedures, and designated liaison roles along with a strong, comprehensive code of conduct, a greater percentage of outsiders on the audit committee and more audit committe meetings reduce the likelihood of crime. According to study conducted by Braun et al. (2001) about the perception of CFE designation respondents agreed that the CFE designation increases the likelihood of user acceptance of formal recommendations regarding preventative internal controls.

In their study Rae and Subramaniam (2008) argued that perceptions of organizational justice are linked with an individual's rationalisation and motivation to commit fraud. They defined organizational justice as a psychological concept that is concerned with the ways in which employees determine if they have been treated fairly in their jobs and the ways in which those determinations influence other work related variables. In their study, they argued that poor perceptions of organizational justice are likely to increase the pressure or motivate an employee to retaliate through employee fraud. Findings of Rae and Subramaniam's study also suggests that organizations which promote a highly ethical environment, and those that actively conduct risk management training of staff and internal audit activities, are likely to have strong internal control procedures. Thus, strategies that promote not only high integrity at the workplace, but also staff training on risk management and the existence of adequate oversight processes through the internal audit function are critical for the detection and prevention of fraud. Study carried out by Persons (2009) examined the voluntary ethics disclosure of fraud and no-fraud companies. Section 406 of the Sarbanes Oxley Act of 2002 requires that every public company have a code of ethics. To ensure that the ethics disclosure is voluntary, in the study Persons examined the disclosures before the SOX ethics rule became effective. Results of the study indicate that earlier voluntary ethics disclosure was negatively associated with fraudulent financial reporting.

\section{Research Methodology}

\section{Research Model and Hypothesis Development}

One of the purposes of the study is to identify the external and internal auditors' opinion regarding the effectiveness of fraud prevention measures for each of the three categories of fraud: fraudulent financial statement, misappropriation of assets and corruption. Thus, the first research question explores: 
RQ1: Which fraud prevention measure is perceived as the most effective in preventing fraudulent financial statement, misappropriation of assets and corruption?

Since three types of fraud are committed in different ways and the main reasons of each fraud differ greatly, the efectiveness of fraud prevention measures may vary among fraud types. Therefore, the following research question has been developed:

RQ2: Are there differences among fraudulent financial statement, misappropriation of assets or corruption regarding the perceived effectiveness of fraud prevention measures?

The research model developed and used in this paper is depicted in Figure 1.

Based on the RQ 2 and research model this study emprically tests the following hypthesis:

H1: There is no difference among fraudulent financial statement, misappropriation of assets or corruption regarding the perceived effectiveness of fraud prevention measures.

\section{Sample Selection}

The research sample consists of 54 external auditors and 92 internal auditors from Turkey. The data for the study was collected through a questionnaire survey. 14 fraud prevention measures are listed in the questionnaire and the respondents were asked to indicate their opinion on the degree of effectiveness of each fraud prevention measures. Each questionnaire item was scored on a fourpoint Likert Scale (1=very ineffective ; 2 =ineffective; 3 =effective; 4 = very effective). Four-point scale is used in order to force participants to choice effectiveness level since the middle option of "neither effective nor ineffective" is not available. A total of 1556 questionnaire were distributed in May 2010. 166 questionnaires were collected, 20 questionnaires were eliminated due to invalid anwers, leaving 146 questionnaires for the empirical analysis.

\section{Relability and Validity}

In this study, contex validity is used in order to examine validity of questionnaire. The first draft of the questionnaire was reviewed by two external auditors and three internal auditors. Then necessary modifications were applied based on feedback from auditors.

Nunnally (1978) suggests that for any research at its early stage a reliability score or alpha that is 0,60 or above is sufficient. As shown in Table 1, Cronbach's Alphas of all types of frauds were found to exceed the threshold set by Nunnally. The value indicates that reliability of the scale of measurement was significantly high.

Table No. 1

\section{Reliability Test (Cronbach's Alpha)}

\begin{tabular}{lcc}
\hline & Number of Items & Cronbach's Alpha \\
Fraudulent Financial Statement & 14 & .827 \\
Misappropriation of Assets & 14 & .839 \\
Corruption & 14 & .841 \\
\hline \hline
\end{tabular}


Annales Universitatis Apulensis Series Oeconomica, 14(1), 2012

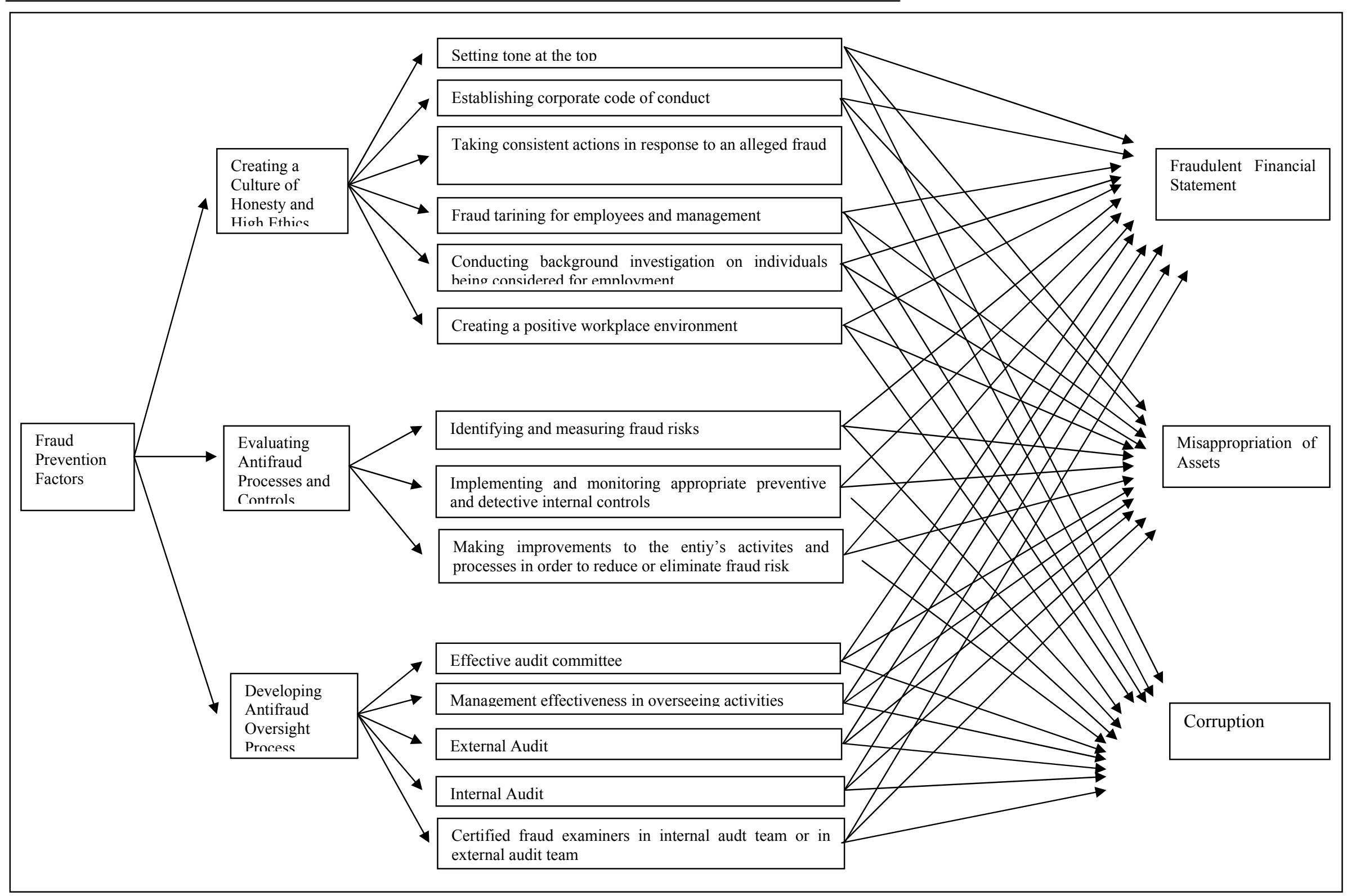

Fig. No.1 - Reseaggh Model 


\section{Results and Analysis}

\section{Descriptive Statistics}

SPSS (Statistical Package for the Social Sciences) software was used in the analysis. The sample comprised of 54 external auditors and 92 internal auditors. In terms of experience, $45.2 \%$ of participants have $1-5$ years experience, $23.3 \%$ of participants have $6-10$ years experience, $19.2 \%$ of participants have 11-15 years experience, $8.9 \%$ of participants have $15-20$ years experience, $3.4 \%$ of participants have more than 20 years experience.

Table 2 presents the means and standard deviations on the perceived effectiveness of fraud prevention measures. As can be seen from Table 2, respondents found effective audit committee to be the most effective measure to prevent fraudulent financial statement, internal audit function to be the most effective measure to prevent misappropriation of assets, and internal audit function to be the most effective measure to prevent corruption.

\section{Descriptive Statistics}

Table No.2

\begin{tabular}{|c|c|c|c|c|c|c|c|}
\hline \multirow[b]{2}{*}{ Fraud Prevention Measures } & \multirow[b]{2}{*}{$\mathbf{N}$} & \multicolumn{2}{|c|}{$\begin{array}{c}\text { Fraudulent } \\
\text { Financial Statement }\end{array}$} & \multicolumn{2}{|c|}{$\begin{array}{l}\text { Misappropriation of } \\
\text { Assets }\end{array}$} & \multicolumn{2}{|c|}{ Corruption } \\
\hline & & Mean & $\begin{array}{l}\text { Standard } \\
\text { Deviation }\end{array}$ & Mean & $\begin{array}{l}\text { Standard } \\
\text { Deviation }\end{array}$ & Mean & $\begin{array}{l}\text { Standard } \\
\text { Deviation }\end{array}$ \\
\hline Creating a Culture of Honesty and High Ethics: & 146 & 3.22 & .565 & 3.26 & .499 & 3.28 & .502 \\
\hline Setting the Tone at the Top & 146 & 3.23 & .837 & 3.18 & .743 & 3.27 & .729 \\
\hline Establishing Corporate Code of Conduct & 146 & 3.23 & .712 & 3.32 & .694 & 3.32 & .759 \\
\hline $\begin{array}{l}\text { Taking Consistent Actions in response to an } \\
\text { Alleged Fraud }\end{array}$ & 146 & 3.47 & .707 & 3.53 & .645 & 3.51 & .656 \\
\hline Fraud Training for Employees and Management & 146 & 3.03 & .882 & 3.02 & .859 & 3.04 & .862 \\
\hline $\begin{array}{l}\text { Conducting Background Investigations on } \\
\text { Individuals Being Considered for Employment }\end{array}$ & 146 & 3.18 & .892 & 3.19 & .841 & 3.27 & .810 \\
\hline Creating a Positive Workplace Environment & 146 & 3.21 & .796 & 3.29 & .716 & 3.30 & .737 \\
\hline Evaluating Antifraud Processes And Controls & 146 & 3.44 & .553 & 3.40 & .597 & 3.42 & .555 \\
\hline Identifying and Measuring Fraud Risks & 146 & 3.32 & .712 & 3.27 & .773 & 3.30 & .698 \\
\hline $\begin{array}{l}\text { Implementing and monitoring Appropriate } \\
\text { Preventive and Detective Internal Controls }\end{array}$ & 146 & 3.45 & .676 & 3.44 & .714 & 3.47 & .687 \\
\hline $\begin{array}{l}\text { Making changes to the entity's acitivities and } \\
\text { processes in order to reduce or eliminate fraud risk }\end{array}$ & 146 & 3.55 & .676 & 3.50 & .726 & 3.49 & .707 \\
\hline Developing an Appropriate Oversight Process: & 146 & 3.48 & .454 & 3.39 & .464 & 3.36 & .501 \\
\hline Effective Audit Committee & 146 & 3.62 & .554 & 3.54 & .577 & 3.51 & .667 \\
\hline $\begin{array}{l}\text { Management Effectiveness in Overseeing } \\
\text { Activities }\end{array}$ & 146 & 3.37 & .734 & 3.40 & .643 & 3.34 & .738 \\
\hline External Audit & 146 & 3.45 & .734 & 3.01 & .913 & 2.93 & .973 \\
\hline Internal Audit & 146 & 3.56 & .632 & 3.60 & .605 & 3.59 & .607 \\
\hline $\begin{array}{l}\text { Certified Fraud Examiners in internal audit team or } \\
\text { in external audit team }\end{array}$ & 146 & 3.39 & .773 & 3.40 & .766 & 3.45 & .715 \\
\hline
\end{tabular}

To analyze the differences in fraud prevention measures' perceived effectiveness among fraudulent financial statement, misappropriation of assets and corruption the Friedman Test was applied. The analysis has been conducted in two stage. At the first stage, analysis was applied for each of the questionnaire items. At the second stage, the same analysis was repeated for the three main fraud prevention measures. Table 3, Table 4 and Table 5 summarizes the results of the tests on the differences in the perceived effectiveness of fraud prevention measures. 
Table No.3

\section{Friedman Test}

\begin{tabular}{|c|c|c|c|c|c|c|c|}
\hline & & Mean Rank & & & & & \\
\hline Fraud Prevention Measures & $\begin{array}{l}\text { Fraudulent } \\
\text { Financial } \\
\text { Statement }\end{array}$ & $\begin{array}{l}\text { Misappropriation } \\
\text { of Assets }\end{array}$ & Corruption & $\mathbf{N}$ & $x^{2}$ & df & $\begin{array}{l}\text { Asymp. } \\
\text { Sig. }\end{array}$ \\
\hline $\begin{array}{l}\text { Creating a Culture of Honesty and High } \\
\text { Ethics: }\end{array}$ & 1.93 & 1.99 & 2.08 & 146 & 3.116 & 2 & .211 \\
\hline Setting the Tone at the Top & 2.01 & 1.94 & 2.05 & 146 & 2.952 & 2 & .229 \\
\hline Establishing Corporate Code of Conduct & 1.90 & 2.03 & 2.07 & 146 & 8.241 & 2 & .016 \\
\hline $\begin{array}{l}\text { Taking Consistent Actions in response to an } \\
\text { Alleged Fraud }\end{array}$ & 1.96 & 2.04 & 2.00 & 146 & 2.634 & 2 & .268 \\
\hline $\begin{array}{l}\text { Fraud Training for Employees and } \\
\text { Management }\end{array}$ & 2.01 & 1.98 & 2.01 & 146 & 0.418 & 2 & .812 \\
\hline $\begin{array}{l}\text { Conducting Background Investigations on } \\
\text { Individuals Being Considered for } \\
\text { Employment }\end{array}$ & 1.97 & 1.98 & 2.05 & 146 & 3.931 & 2 & .140 \\
\hline Creating a Positive Workplace Environment & 1.93 & 2.02 & 2.04 & 146 & 4.965 & 2 & .084 \\
\hline $\begin{array}{l}\text { Evaluating Antifraud Processes and } \\
\text { Controls }\end{array}$ & 2.04 & 1.96 & 1.99 & 146 & 1.909 & 2 & .385 \\
\hline Identifying and Measuring Fraud Risks & 2.01 & 1.98 & 2.01 & 146 & 0.651 & 2 & .722 \\
\hline $\begin{array}{l}\text { Implementing and monitoring Appropriate } \\
\text { Preventive and Detective Internal Controls }\end{array}$ & 2.00 & 1.97 & 2.03 & 146 & 1.471 & 2 & .479 \\
\hline $\begin{array}{l}\text { Making changes to the entity's acitivities } \\
\text { and processes in order to reduce or } \\
\text { eliminate fraud risk }\end{array}$ & 2.05 & 1.98 & 1.97 & 146 & 3.524 & 2 & .172 \\
\hline $\begin{array}{l}\text { Developing an Appropriate Oversight } \\
\text { Process: }\end{array}$ & 2.23 & 1.93 & 1.85 & 146 & 28.190 & 2 & .000 \\
\hline $\begin{array}{l}\text { Effective Audit Committee or Board of } \\
\text { Directors }\end{array}$ & 2.08 & 1.97 & 1.95 & 146 & 8.060 & 2 & .018 \\
\hline $\begin{array}{l}\text { Management Effectiveness in Overseeing } \\
\text { Activities }\end{array}$ & 2.00 & 2.04 & 1.96 & 146 & 3.408 & 2 & .182 \\
\hline External Audit & 2.31 & 1.88 & 1.80 & 146 & 72.080 & 2 & .000 \\
\hline Internal Audit & 1.98 & 2.01 & 2.01 & 146 & 0.779 & 2 & 677 \\
\hline $\begin{array}{l}\text { Certified Fraud Examiners in internal audit } \\
\text { team or in external audit team }\end{array}$ & 1.96 & 2.00 & 2.04 & 146 & 4.092 & 2 & .129 \\
\hline
\end{tabular}

Table No.4

\section{Wilcoxon Test for Main Fraud Prevention Measures}

\begin{tabular}{|c|c|c|c|c|c|c|c|c|}
\hline & \multicolumn{2}{|c|}{ Friedman Test } & \multicolumn{2}{|c|}{$\begin{array}{c}\text { Wilcoxon Test } \\
\text { (Fraudulent } \\
\text { Financial } \\
\text { Statement- } \\
\text { Misappropriation } \\
\text { of Assets) }\end{array}$} & \multicolumn{2}{|c|}{$\begin{array}{l}\text { Wilcoxon Test } \\
\text { (Fraudulent } \\
\text { Financial } \\
\text { Statement- } \\
\text { Corruption) }\end{array}$} & \multicolumn{2}{|c|}{$\begin{array}{c}\text { Wilcoxon Test } \\
\text { (Misappropriation } \\
\text { of Assets - } \\
\text { Corruption) }\end{array}$} \\
\hline & $\chi^{2}$ & $\begin{array}{c}\text { Asymp. } \\
\text { Sig. }\end{array}$ & $\mathbf{Z}$ & $\begin{array}{l}\text { Asymp. } \\
\text { Sig. (2- } \\
\text { tailed) }\end{array}$ & $\mathbf{Z}$ & $\begin{array}{l}\text { Asymp. } \\
\text { Sig. (2- } \\
\text { tailed) }\end{array}$ & $\mathbf{Z}$ & $\begin{array}{l}\text { Asymp. } \\
\text { Sig. (2- } \\
\text { tailed) } \\
\end{array}$ \\
\hline $\begin{array}{l}\text { Establishing Corporate Code of } \\
\text { Conduct }\end{array}$ & 8.241 & .016 & -1.880 & .060 & -1.463 & .144 & -.061 & .951 \\
\hline $\begin{array}{l}\text { Effective Audit Committee or Board of } \\
\text { Directors }\end{array}$ & 8.060 & .018 & -2.180 & .029 & -2.111 & .035 & -.688 & .491 \\
\hline External Audit & 72.080 & .000 & -5.849 & .000 & -6.173 & .000 & -2.047 & .041 \\
\hline
\end{tabular}




\section{Wilcoxon Test for Fraud Prevention Measures}

\begin{tabular}{|c|c|c|c|c|c|c|c|c|}
\hline & \multicolumn{2}{|c|}{ Friedman Test } & \multicolumn{2}{|c|}{$\begin{array}{l}\text { Wilcoxon Test } \\
\text { (Fraudulent } \\
\text { Financial } \\
\text { Statement- } \\
\text { Misappropriation } \\
\text { of Assets) }\end{array}$} & \multicolumn{2}{|c|}{$\begin{array}{l}\text { Wilcoxon Test } \\
\text { (Fraudulent } \\
\text { Financial } \\
\text { Statement- } \\
\text { Corruption) }\end{array}$} & \multicolumn{2}{|c|}{$\begin{array}{c}\text { Wilcoxon Test } \\
\text { (Misappropriation } \\
\text { of Assets - } \\
\text { Corruption) }\end{array}$} \\
\hline & $x^{2}$ & $\begin{array}{l}\text { Asymp. } \\
\text { Sig. }\end{array}$ & $\mathbf{Z}$ & $\begin{array}{l}\text { Asymp. } \\
\text { Sig. (2- } \\
\text { tailed) }\end{array}$ & $\mathbf{Z}$ & $\begin{array}{l}\text { Asymp. } \\
\text { Sig. (2- } \\
\text { tailed) }\end{array}$ & $\mathbf{Z}$ & $\begin{array}{l}\text { Asymp. } \\
\text { Sig. (2- } \\
\text { tailed) }\end{array}$ \\
\hline $\begin{array}{l}\text { Developing an Appropriate Oversight } \\
\text { Process }\end{array}$ & 28.190 & .000 & -3.969 & .000 & -4.198 & .000 & -1.488 & .137 \\
\hline
\end{tabular}

\section{Findings for the Analysis of Main Fraud Prevention Measures}

Abovementioned analysis was repeated for the three main fraud prevention measures and the results of the Friedman test is shown in Table 3. The value of $\chi^{2}$ came out to be $3.116(p<0.05)$ for creating a culture of honesty and $1.909(\mathrm{p}<0.05)$ for high ethics and evaluating antifraud processes and controls. Those values indicated that the preceived effectiveness of those measures did not significantly change among three types of fraud. On the other hand, the value of $\chi^{2}$ came out to be $28.190(\mathrm{p}<0.05)$ for developing an appropriate oversight process. This value indicates that respondents have significant difference in their opinion regarding the effectiveness of developing an appropriate oversight process in preventing fraudulent financial statement, misappropriation of assets and corruption. In order to follow this finding, Wilcoxon tests with the Bonferroni correction was used. The Wilcoxon test indicated that the mean ranks of fraudulent financial statement and misappropiration of assets, additionally the mean ranks of fraudulent financial statement and corruption had significant differences. As a result it can be concluded that fraudulent financial statement had the highest ranking (mean rank=2.23) compared to misappropriation of assets (mean rank=1.93) and corruption (1.85). Thus it can be concluded that developing an appropriate oversight process is more effective to prevent fraudulent financial reporting compare to preventing misappropriation of assets and corruption.

\section{Findings for the Analysis of Fraud Prevention Measures}

Friedman test was applied to examine the degree of perceived effectiveness of each of the fraud prevention measures among fraudulent financial statements, misappropriation of assets and corruption. The results of the Friedman test in Table 3 show that there were significant differences in terms of auditors' ranking of fraudulent financial statements, misappropriation of assets and corruption for the following measures: establishing corporate code of conducts $\left(\chi^{2}(2)=8,241\right.$, $\mathrm{p}<.05)$, effective audit commitee $\left(\chi^{2}(2)=8,060, \mathrm{p}<.05\right)$, and external auditors $\left(\chi^{2}(2)=72,080, p<.05\right)$. For those measures, Wilcoxon tests were used to follow up this findings. A Bonferroni correction was applied and results are reported at a .0167 level of significance. It appeared that perceived effectiveness of establishing corporate code of conducts and effective audit commitee did not significantly changed between each pairs of fraud. On the other hand, for external auditor function, Wilcoxon test indicated that the mean ranks of fraudulent financial statement and misappropiration of assets, additionally the mean ranks of fraudulent financial statement and corruption had significant differences. As a result it can be concluded that fraudulent financial statement had the highest ranking (mean rank=2.31) compared to misappropriation of assets (mean rank=1.88) and corruption (1.80). Thus it can be concluded that external audit is more effective to prevent fraudulent financial reporting compare to preventing misappropriation of assets and corruption. 


\section{Conclusion, Limitation and Suggestions}

\section{Conclusion}

The main focus of this study was to test the level of perceived effectiveness of fraud prevention measures. Furthermore, this study examined whether there are differences among fraudulent financial statement, misappropriation of assets and corruption regarding the perceived effectiveness of fraud prevention measures. The results have shown that external audit is more effective to prevent fraudulent financial reporting compare to preventing misappropriation of assets and corruption. Similarly, developing an appropriate oversight process is more effective to prevent fraudulent financial reporting compare to preventing misappropriation of assets and corruption.

\section{Limitations and Suggestions for Future Research}

The first limitation in the study is the fact that, the small size of the sample limits the generalizablity of the results to the wider population. Another limitation may be regarding the participants' experience. The composition of the sample could potentially limit the generalization of the results because $45.2 \%$ of participants have less than 5 years experience. However, the results obtained from the analysis of this type of sample can still provide significant outcomes.

For future research, with the aim of comparing opinion of auditors and managers regarding the effectiveness of fraud prevention measures, similar questionanire can be prepared for managers.

\section{References}

1. Albrecht W. S., Albrecht C. C., Albrecht C.O., Zimbelman M. F., 2009. Fraud Examination. South Western.

2. Alleyne, P., Howard M., 2005. An exploratory study of auditors' responsibility for fraud detection in Barbados, Managerial Auditing Journal, Vol. 20 No. 3, pp. 284-303.

3. American Institute of Certified Public Accountants (AICPA), 2002. Consideration of Fraud in a Financial Statement Audit. Statement on Auditing Standards No.99. New York, NY.

4. Association of Certified Fraud Examiners (ACFE), Tone at the Top: How Management Can Prevent Fraud in the Workplace. http://www.acfe.com/documents/tone-at-the-topresearch.pdf

5. Association of Certified Fraud Examiners (ACFE), 2010. Report to the Nations on Occupational Fraud and Abuse.

6. Ata H. A., Uğurlu M., Altun M.Ö., 2009. Finansal tablo hilelerinin önlenmesinde denetçi algılamaları, Gaziantep Üniversitesi Sosyal Bilimler Dergisi, 8 (1), pp.215-230.

7. Beasley M. S., Carcello J. V., Hermanson,D.R., Lapides P.D., 2000. Fraudulent financial raporting: consideration of industry traits and corporate governance mechanisms, Accounting Horizons, Vol.14, No.4., December 2000, pp. 441-454.

8. Beasley M.S., 1996. An emprical analysis of the relation between the board of director and composition and financial statement fraud, The Accounting Review, 71, pp. 443-465.

9. Biegelman M. T., Bartow J. T., 2006. Executive Roadmap to Fraud Prevention and Internal Control, John Wiley \&Sons, New Jersey.

10. Braun R. L., Mauldin D.S., Fischer M. A., 2001. The CFE designation in perspective, The CPA Journal, April, pp.43-48.

11. Carpenter T. D., Reimers J. L., 2005. Unethical and fraudulent financial reporting: Applying the theory of planned behavior, Journal of Business Ethics, 60(2), pp.115-129.

12. Coenen L. T., 2008. Essentials of Corporate Fraud, John Wiley and Sons, New Jersey.

13. Coram P., Ferguson C., Moroney R., 2008. Internal audit, alternative audit structures and the level of misappropriateion of assets fraud. Accounting and Finance, 48, 543- 559. 
14. James K. L., 2003. The effects of internal audit structure on perceived financial statement fraud prevention, Accounting Horizons, Vol.17 No 4., pp 315-327.

15. Krummeck S., 2000. The role of ethics in fraud prevention: A practitioner's perspective, Business Ethics: A European Review, 9 (4), pp.268-272.

16. Messier F. W., Glover S. M., Prawitt D.F., 2008. Auditing \& Assurance Services a Systematic Approach., McGraw Hill Irwin, New York, NY

17. Nunnally J. C., 1978. Psychometric Theory, McGraw-Hill, New York, 1978, pp. 23-45.

18. Özbirecekli M., Süslü C., 2005. Bağımsız Denetim Firmalarının Yolsuzluk Riski Faktörlerini Değerleme Uygulamaları ve Türkiye'deki Bağımsız Denetim Firmaları Üzerine Karş1laştırmalı Bir Araştırma II, Muhasebe ve Finansman, 28(1), pp.48-66.

19. Persons O.S., 2009. Audit committee characteristics and earlier voluntary ethics disclosure among fraud and no-fraud firms, International Journal of Disclosure and Governance, Vol. 6, 4, pp.284-297.

20. Rae K., Subramaniam N., 2008. Quality of internal control procedures: antecedents and moderating effect on organisational justice and employee fraud Managerial Auditing Journal, Vol. 23. , No:2, pp. 104-124.

21. Reding K. F., Sobel P. J., Anderson U. L., Head M. J., Ramamoorti S., Salamasick M., 2007. Internal Auditing:Assurance\&Consulting Services. The IIA Research Foundation.

22. Rezaee Z., 2002. Financial Statement Fraud Prevention and Detection. John Wiley and Sons.

23. Schnatterly K., 2003. Increasing firm value through detection and prevention of whitecollar crime. Strategic Management Journal, 24: 587-614.

24. Uzun H., Szewezyk H.S., Varma R., 2004. Board composition and corporate fraud. Financial Analyst Journal, May/June,, pp.33-34.

Appendix No.1

\section{Reliability Test (Cronbach’s Alpha)}

\begin{tabular}{lcc}
\hline & Number of Items & Cronbach's Alpha \\
\hline Fraudulent Financial Statement & 14 & .827 \\
Misappropriation of Assets & 14 & .839 \\
Corruption & 14 & .841 \\
\hline
\end{tabular}

